\title{
PENYUSUNAN DAN PENERAPAN METODE REGRESSION ADAPTIVE NEURO FUZZY INFERENCE SYSTEM (RANFIS) UNTUK ANALISIS DATA KURS IDR/USD
}

\author{
Lamik Nabil Mu'affa ${ }^{1}$, Tarno ${ }^{2}$, Suparti $^{3}$ \\ 1,2,3 Departemen Statistika, Fakultas Sains dan Matematika, Universitas Diponegoro \\ e-mail : tarno.stat@gmail.com
}

\begin{abstract}
The exchange rate of rupiah is one of the important prices in an open economy because the exchange rate can be used as a toolto measure the economic condition of a country. The movement of the rupiah exchange rate affected the Indonesian economy, maintaining the stability of the ru piah exchange rate became an important thing to do. In an effort to maintain the stability of the rupiah exchange rate, the factors that influence it must first be identified. Several factors affect the IDR/ USD exchange rate, namely the large trade price index, foreign exchange reserves, money supply and interest rates. In this study, the Regression Adaptive Neuro Fuzzy Inference System (RANFIS) method was used to analyze the effect of predictor variables on IDR / USD exchange rates. The optimal RANFIS model is strongly influenced by three things, namely the determination of input predictor variable, membership functions, and number of clusters. Determination of the optimal RANFIS model is measured based on the smallest MAPE in-s ample. Based on empirical studies applied to predictor variables on IDR/ USD exchange rates, it was found that the RANFIS model was optimal, namely with 3 predictor variable in puts consisting of large trade price indexvariables, money supply and interest rates; with the gauss membership function; 2 clusters and rules produce an MAPE in-s ample of $1.93 \%$ and an MAPE out-sample of $2.68 \%$, so the performance of the RANFIS model has a very good level of accuracy.
\end{abstract}

Keywords: Exchange rate, regression analysis, ANN, fuzzy, RANFIS

\section{PENDAHULUAN}

Menurut Adiningsih et al. (1998), nilai tukar rupiah adalah harga rupiah terhadap mata uang negara lain. Jadi, nilai tukar rupiah merupakan nilai mata uang rupiah yang ditranslasikan ke dalam mata uang negara lain. Misalnya nilai tukar rupiah terhadap dolar Amerika, nilai tukar rupiah terhadap Euro, dan lain sebagainya. Kurs dapat dijadikan alat untuk mengukur kondisi perekonomian suatu negara. Nilai mata uang yang stabil menunjukkan bahwa negara tersebut memiliki kondisi ekonomi yang relatif baik atau stabil. Ketidakstabilan nilai tukar ini akan mempengaruhi arus modal dan perdagangan internasional (Triyono, 2008).

Pelemahan nilai tukar rupiah yang cukup ekstrem bisa mempengaruhi daya beli dan sektor riil. Melemahnya nilai tukar rupiah terhadap dolar juga memberikan banyak dampak di berbagai sektor usaha, terutama pada usaha dengan bahan baku yang berasal dari impor seperti pengusaha tahu dan tempe, peternak hingga pengusaha elektronik dan otomotif.

Berdasarkan latar belakang tersebut, perlu dilakukan penelitian untuk mengkaji lebih lanjut faktor-faktor yang mempengaruhi kurs Rupiah (IDR) terhadap Dollar Amerika Serikat (USD). Salah satu alat untuk menganalisis faktor-faktor yang mempengaruhi kurs IDR/USD adalah analisis regresi linier berganda. Menurut Suliyanto (2011), analisis regresi linear berganda merupakan analisis yang digunakan untuk memprediksi satu variabel dependen (respon) berdasarkan dua atau lebih variabel independen (prediktor). Namun penggunaan teknik Regresi Linier Berganda memiliki persyaratan asumsi-asumsi yang mendasarinya dan sering ditemukan bahwa data yang akan dimodelkan tidak memenuhi asumsi-asumsi klasik yang disyaratkan tersebut. Jika data yang tidak memenuhi asumsiasumsi klasik tersebut tetap dimodelkan dengan menggunakan pendekatan tersebut, maka akan terjadi pelanggaran asumsi yang akan mengakibatkan hasil yang diperoleh menjadi jauh dari harapan, tidak efisien, tidak konsisten atau bahkan menjadi bias.

Salah satu metode alternatif yang dapat digunakan untuk menangani permasalahan tersebut adalah dengan menggunakan metode Artificial Neural Network (ANN) atau 
Jaringan Syaraf Tiruan. Salah satu bagian dari Jaringan Syaraf Tiruan tersebut adalah Regression Adaptive Neuro Fuzzy Inference System (RANFIS). Menurut Jang et al. (1997), Regression Adaptive Neuro Fuzzy Inference System (RANFIS) merupakan analisis regresi yang dibangun dari jaringan syaraf tiruan yang menerapkan sistem inferensi fuzzy model Takagi Sugeno Kang (TSK) yang terdiri atas satu lapisan input, tiga lapisan tersembunyi (hidden layer), dan satu lapisan output.

Oleh karena itu, dalam penelitian ini diterapkan metode Regression Adaptive Neuro Fuzzy Inference System (RANFIS) yang digunakan untuk menganalisis pengaruh variabelvariabel prediktor : posisi cadangan devisa, suku bunga, Indeks Harga Perdagangan Besar (IHPB), dan uang beredar terhadap kurs IDR/USD.

\section{TINJAUAN PUSTAKA}

\subsection{Analis is Regresi Linear Berganda}

Suliyanto (2011) menjelaskan bahwa analisis regresi linear berganda merupakan analisis yang digunakan untuk memprediksi satu variabel respon berdasarkan dua atau lebih variabel prediktor. Apabila terdapat variabel prediktor sebanyak $k$, maka model regresi linear berganda dapat dinyatakan sebagai berikut:

$$
y_{i}=\beta_{0}+\beta_{1} x_{i 1}+\beta_{2} x_{i 2}+\cdots+\beta_{k} x_{i k}+\varepsilon_{i}
$$

dengan variabel $y_{i}$ dinamakan variabel respon, variabel $x_{i j}$ disebut variabel prediktor, $\beta_{0}$ adalah konstanta (intersept), dan $\beta_{j}$ adalah koefisien regresiatau nilai parameter dengan $i=1,2, \ldots n$ dan $j$ $=1,2, \ldots k$. dengan $\mathrm{n}$ adalah banyaknya observasi, dan $\mathrm{k}$ adalah banyaknya regressor.

Untuk menduga parameter regresi pada Persamaan (1) dapat digunakan metode kuadrat terkecil, Adapun model dugaan pada Persamaan (1) dapat dinyatakan sebagi berikut:

$$
\hat{y}=\hat{\beta}_{0}+\hat{\beta}_{1} x_{1}+\hat{\beta}_{2} x_{2}+\cdots+\hat{\beta}_{k} x_{k}
$$

\subsection{Regression Adaptive Neuro Fuzzy Inference System (RANFIS)}

Regression Adaptive Neuro Fuzzy Inference System (RANFIS) merupakan analisis regresi yang dibangun dari jaringan syaraf tiruan yang menerapkan sistem inferensi fuzzy model Takagi Sugeno Kang (TSK) yang terdiri atas satu lapisan input, tiga lapisan tersembunyi (hidden layer), dan satu lapisan output (Jang et al., 1997). Metode RANFIS juga merupakan metode yang mana dalam melakukan penyetelan aturan digunakan algoritma pembelajaran terhadap sekumpulan data dan juga memungkinkan aturan-aturan untuk beradaptasi (Kusumadewi dan Hartati, 2006).

Tarno et al. (2013), menjelaskan apabila diberikan dua input yang terdiri atas $x_{1}$ dan $x_{2}$, dengan dua fungsi keanggotaan serta satu output berupa $\hat{y}$ maka dapat dibentuk 2 aturan pada basis aturan model Sugeno Orde Satu yaitu:

\section{Aturan 1:}

IF $\left(x_{1}\right.$ is $\left.A_{1}\right)$ and $\left(x_{2}\right.$ is $\left.B_{1}\right)$ THEN $y_{1}=p_{11} x_{1}+q_{12} x_{2}+r_{1}$

Aturan 2:

IF $\left(x_{1}\right.$ is $\left.A_{2}\right)$ and $\left(x_{2}\right.$ is $\left.B_{2}\right)$ THEN $y_{2}=p_{21} x_{1}+q_{22} x_{2}+r_{2}$

dengan, $x_{1}$ is $A_{1}$ dan $x_{2}$ is $B_{1} ; x_{1}$ is $A_{2}$ dan $x_{2}$ is $B_{2}$ merupakan premis atau bagian nonlinear, $y_{1}=p_{11} x_{1}+q_{12} x_{2}+r_{1}$ dan $y_{2}=p_{21} x_{1}+q_{22} x_{2}+r_{2}$ adalah konsekuen atau linear. $p_{11}, q_{12}$, $r_{1}, p_{21}, q_{22}$, dan $r_{2}$ adalah parameter konsekuen atau linear. $A_{1}, B_{1}, A_{2}$, dan $B_{2}$ adalah parameter premis atau nonlinear.

Jika derajat pengaktifan (the firing strength) setiap aturan adalah $w_{1}$ dan $w_{2}$ untuk $y_{1}$ dan $y_{2}$ dengan output $\hat{y}$ maka dapat dihitung:

$$
\begin{aligned}
& \hat{y}=\frac{w_{1} y_{1}+w_{2} y_{2}}{w_{1}+w_{2}} \\
& \hat{y}=\bar{w}_{1} y_{1}+\bar{w}_{2} y_{2}
\end{aligned}
$$

Berdasarkan basis aturan di atas, arsitektur jaringan RANFIS dapat dilihat pada Gambar 1. 


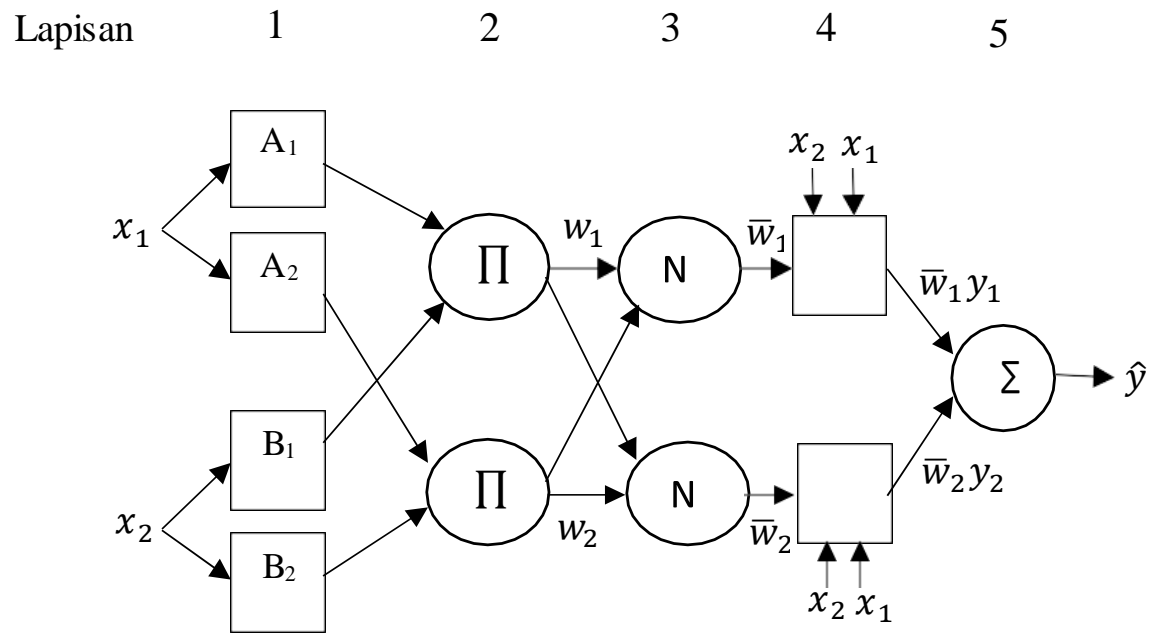

Gambar 1. Arsitektur Jaringan RANFIS

Menurut Jang et al. (1997), arsitektur jaringan RANFIS terdiri dari lima lapisan (layer) yang memiliki fungsi sebagai berikut:

a. Lapis an 1

Setiap neuron pada lapisan pertama adalah adaptif terhadap parameter fungsi aktivasi. Output lapisan ini berupa derajat keanggotaan (Membership Functions) yang diberikan oleh fungsi keanggotaan input.

Fungsi keanggotaan input-nya sebagai berikut:

$$
\mu_{A_{1}}\left(x_{1}\right), \mu_{A_{2}}\left(x_{1}\right), \mu_{B_{1}}\left(x_{2}\right) \text {, dan } \mu_{B_{2}}\left(x_{2}\right)
$$

Misalnya, diberikan fungsi keanggotaan Gauss sebagai berikut.

$$
\mu\left(x_{i}\right)=e^{-\frac{1}{2}\left(\frac{x-c}{\sigma}\right)^{2}} ; \text { dengan } \mathrm{i}=1,2
$$

dengan $c$ dan $\sigma$ adalah parameter pada lapisan ini. $c$ adalah rata-rata dan $\sigma$ adalah standar deviasi. Parameter-parameter pada lapisan ini disebut dengan parameter premis.

\section{b. Lapisan 2}

Setiap neuron pada lapisan kedua berupa neuron tetap atau non adaptif yang disimbolkan dengan $\Pi$. Output lapisan ini berupa hasil dari input yang umumnya menggunakan operator AND dalam perhitungan. Output setiap neuron dalam lapis an ini menyatakan derajat pengaktifan tiap aturan (the firing strength of a rule) yang disimbolkan dengan $w_{i}$ dari aturan ke- $i$ dan dinyatakan dalam rumus: $w_{i}=\mu_{A_{i}}(x) \mu_{B_{i}}(x), i=1,2$

\section{c. Lapisan 3}

Setiap neuron pada lapisan ketiga berupa neuron tetap atau non adaptif yang disimbolkan dengan N. Output setiap neuron berupa derajat pengaktifan ternormalisasi (the normalized firing strength). Output lapisan ini disimbolkan dengan $\bar{w}_{i}$ dan dinyatakan dalam rumus: $\bar{w}_{i}=$ $\frac{w_{i}}{w_{1}+w_{2}}, i=1,2$

\section{d. Lapisan 4}

Setiap neuron pada lapisan keempat berupa neuron adaptif. Output setiap neuron disimbolkan dengan $\bar{w}_{i} y_{i}$ dan dinyatakan dalam rumus:

$\bar{w}_{i} y_{i}=\bar{w}_{i}\left(p_{i 1} x_{1}+q_{i 2} x_{2}+r_{i}\right), i=1,2$ 
dengan $\bar{w}_{i}$ adalah normalized firing strength pada lapisan ketiga dan $p_{i 1}, q_{i 2}, r_{i}$ adalah parameter-parameter pada lapisan keempat. Parameter-parameter pada lapisan keempat dinamakan consequent parameters (parameter konsekuen).

e. Lapisan 5

Pada lapisan ini hanya terdapat satu neuron non adaptif atau tetap yang merupakan jumlahan dari semua input dari lapisan keempat.

Output lapisan 5 adalah :

$$
\begin{aligned}
& \hat{y}=\sum_{i=1}^{2} \bar{w}_{i} y_{i} \\
& \hat{y}=\sum_{i=1}^{2} \bar{w}_{i}\left(p_{i 1} x_{1}+q_{i 2} x_{2}+r_{i}\right) \\
& \hat{y}=\bar{w}_{1}\left(p_{11} x_{1}+q_{12} x_{2}+r_{1}\right)+\bar{w}_{2}\left(p_{21} x_{1}+q_{22} x_{2}+r_{2}\right)
\end{aligned}
$$

\subsection{Algoritma Pembelajaran Hybrid}

Menurut Jang et al. (1997), Regression Adaptive Neuro Fuzzy Inference System (RANFIS) mengaplikasikan algoritma pembelajaran hibrida (hybrid) dalam sistemnya untuk mengidentifikasi parameter. Wijiyanto et al. (2012) menjelaskan bahwa algoritma hybrid akan menduga paramater-parameter konsekuen $\left(p_{11}, q_{12}, r_{1}, p_{21}, q_{22}, r_{2}\right)$ secara maju (forward) menggunakan metode least squares dan menduga parameter-parameter premis secara mundur (backward) menggunakan metode gradient descent.

\subsection{Ukuran Akurasi}

Ariefianto (2012) menjelaskan bahw a ukuran akurasi menunjukkan seberapa besar keakuratan variabel respon yang diprediksi dengan data respon aktual. Ukuran akurasi yang digunakan yaitu MAPE (Mean Absolute Prediction Error)

MAPE dirumuskan sebagai berikut:

$$
M A P E=\frac{1}{n} \sum_{i=1}^{n}\left|\frac{y-\hat{y}}{y}\right| \times 100 \%
$$

dengan $\mathrm{n}$ adalah banyak data pada observasi, $\hat{y}$ adalah output pada model (prediksi), dan $y$ adalah data asli atau target output.

\section{METODE PENELITIAN}

\subsection{Data dan Variabel Penelitian}

Data yang digunakan dalam penelitian ini yaitu data dari variabel dependen/ variabel respon kurs USD/IDR dan data dari 4 variabel independen/prediktor yang terdiri dari variabel Indeks Harga Perdagangan Besar (IHPB), Cadangan Devisa (CD), Uang Beredar (UB), dan Suku Bunga (SB). Data diatas diperoleh dari BI (www.bi.go.id). Data yang digunakan merupakan data bulanan periode Januari 2011 sampai Desember 2018.

\subsection{Teknik Pengolahan Data}

Software yang digunakan dalam penelitian ini adalah MATLAB R2015b. Pada penelitian ini, analisis yang digunakan pada tahap pertama yaitu menentukan variabelvariabel prediktor dengan cara trial and error sebagai input pada RANFIS. Berdasarkan hasil pemodelan RANFIS akan dipilih model terbaik melalui tingkat akurasi MAPE terkecil dari RANFIS (Regression Adaptive Neuro Fuzzy Inference System).

Langkah-langkah yang dilakukan dalam penyusunan dan penerapan model RANFIS sebagai berikut:

1. Memasukkan variabel prediktor satu persatu mulai dari 1 variabel sampai kombinasi 4 variabel.

2. Membagi data menjadi in-sample dan out-sample. 
3. Mendefinisikan banyaknya cluster dan aturan menggunakan Fuzzy C-Means serta fungsi keanggotaan (Membership Functions) gauss untuk variabel input.

4. Melakukan pembangkitan aturan fuzzy IF-THEN untuk menghasilkan variabel output berdasarkan input, cluster, aturan, dan fungsi keanggotaan. Aturan fuzzy IF-THEN menggunakan model Sugeno orde satu.

5. Melakukan pelatihan Fuzzy Inference System (FIS) pada in-sample dengan algoritma hybrid. Parameter konsekuen diestimasi menggunakan LSE Rekursif dan parameter premis disesuaikan dengan backpropagation konsep gradient descent.

6. Menentukan nilai prediksi pada in-sample dan out-sample.

7. Menghitung MAPE pada in-sample dan out-sample.

8. Menentukan model terbaik RANFIS berdasarkan nilai MAPE terkecil pada in-sample.

9. Mengukur tingkat akurasi model terbaik berdasarkan nilai MAPE out-sample.

\section{ANALISIS DAN PEMBAHASAN}

Analisis data dengan Regression Adaptive Neuro Fuzzy Inference System (RANFIS) dimulai dengan memasukkan data dari varieabel-variabel prediktor dan variabel respon. Lalu membagi data menjadi 2 bagian yang terdiri dari in-sample sebanyak 77 data (80\%) dari periode Januari 2011 sampai Mei 2017 dan out-sample sebanyak 19 data (20\%) dari periode Juni 2017 sampai Desember 2018. Data in-sample merupakan data yang digunakan untuk tahap pelatihan, sedangkan data out-sample adalah data yang digunakan untuk tahap pengujian. Langkah selanjutnya yaitu menentukan input optimal untuk model RANFIS dari variabel-variabel prediktor. Pada Penelitian ini, penentuan input optimal menggunakan teknik Fuzzy C-Means (FCM) dengan cluster sebanyak 2. Fungsi Keanggotaan (FK) yang digunakan adalah fungsi gauss.

Setelah menentukan input optimal yang digunakan dalam RANFIS, langkah selanjutnya yaitu menentukan banyaknya cluster dan aturan. Pada Penelitian ini, penentuan cluster dan aturan menggunakan teknik Fuzzy C-Means (FCM). Pada teknik FCM, jumlah aturan sama dengan banyaknya cluster yang ditentukan, maka tidak ada kombinasi dalam pembentukan aturan. Untuk melakukan pembangkitan FIS dengan teknik FCM, digunakan perintah genfis3 pada MATLAB. Kemudian, dilakukan pelatihan menggunakan algoritma hybrid dan akan menghasilkan MAPE pada in-sample dan outsample. Model RANFIS optimal dipilih berdasarkan nilai MAPE pada in-sample yang terkecil. Sedangkan nilai MAPE pada out-sample digunakan untuk evaluasi kinerja model RANFIS.

\subsection{Pemilihan Input Optimal dari Variabel Prediktor untuk Model RANFIS}

Sebelum melakukan pemodelan pada RANFIS, terlebih dahulu dilakukan pemilihan input optimal yang nantinya akan menghasilkan model terbaik. Dalam pemilihan input optimal akan dibandingkan sebanyak 15 input yang dihasilkan dari kombinasi masingmasing variabel prediktor. Input variabel prediktor yang optimal dipilih berdasarkan nilai MAPE in-sample yang terkecil. Input optimal tersebut merupakan variabel prediktor yang memiliki pengaruh terbesar terhadap variabel respon dan akan menghasilkan model yang terbaik. Nilai MAPE Model RANFIS dengan 15 input tersaji pada Tabel 1. 
ISSN: 2339-2541

JURNAL GAUSSIAN, Volume 9, Nomor 2, Tahun 2020, Halaman 193-203

Online di: https://ejournal3.undip.ac.id/index.php/gaussian/

Tabel 1. Nilai MAPE Model RANFIS dengan 1 Input

\begin{tabular}{|c|c|c|c|c|c|c|}
\hline \multirow{2}{*}{ Input } & \multirow{2}{*}{ Data } & \multicolumn{5}{|c|}{ Nilai MAPE (\%) untuk Ulangan ke } \\
\hline & & 1 & 2 & 3 & 4 & 5 \\
\hline \multirow{2}{*}{ IHPB } & in-sample & 3,72 & 3,72 & 3,72 & 3,72 & 3,72 \\
\hline & out-sample & 12,67 & 12,67 & 12,67 & 12,67 & 12,67 \\
\hline \multirow{2}{*}{$\mathrm{CD}$} & in-sample & 15,66 & 15,66 & 15,66 & 15,66 & 15,67 \\
\hline & out-sample & 16,44 & 16,44 & 16,50 & 16,45 & 16,36 \\
\hline \multirow{2}{*}{ UB } & in-sample & 11,25 & 11,72 & 13,11 & 12,07 & 11,80 \\
\hline & out-sample & 11,80 & 12,07 & 15,43 & 13,44 & 12,92 \\
\hline \multirow{2}{*}{ SB } & in-sample & 7,51 & 7,51 & 7,51 & 7,51 & 7,51 \\
\hline & out-sample & 16,92 & 16,92 & 16,92 & 16,92 & 16,92 \\
\hline \multirow{2}{*}{ IHPB,CD } & in-sample & 8,27 & 8,25 & 8,26 & 8,27 & 8,26 \\
\hline & out-sample & 13,50 & 13,44 & 13,44 & 13,55 & 13,47 \\
\hline \multirow{2}{*}{ IHPB,UB } & in-sample & 2,35 & 2,36 & 2,75 & 2,65 & 2,24 \\
\hline & out-sample & 4,49 & 4,67 & 5,09 & 3,83 & 3,82 \\
\hline \multirow{2}{*}{ IHPB,SB } & in-sample & 2,83 & 2,83 & 2,83 & 2,83 & 2,83 \\
\hline & out-sample & 9 & 9 & 9 & 9 & 9 \\
\hline \multirow{2}{*}{ CD,UB } & in-sample & 36,44 & 36 & 34,98 & 34,05 & 32,32 \\
\hline & out-sample & 38,80 & 40,22 & 37,34 & 43,40 & 39,38 \\
\hline \multirow{2}{*}{$\mathrm{CD}, \mathrm{SB}$} & in-sample & 10,77 & 10,64 & 10,25 & 10,86 & 10,65 \\
\hline & out-sample & 10,63 & 10,93 & 11,31 & 11,16 & 10,79 \\
\hline \multirow{2}{*}{$\mathrm{UB}, \mathrm{SB}$} & in-sample & 11,64 & 13,84 & 12,39 & 11,25 & 12,22 \\
\hline & out-sample & 47,66 & 44,38 & 39,89 & 34,42 & 40,71 \\
\hline \multirow{2}{*}{ IHPB,CD,UB } & in-sample & 55,47 & 56,56 & 58,69 & 55,32 & 54,98 \\
\hline & out-sample & 40,79 & 44,38 & 47,98 & 35,13 & 42,97 \\
\hline \multirow{2}{*}{ IHPB,CD,SB } & in-sample & 5,46 & 5,48 & 5,45 & 5,42 & 5,43 \\
\hline & out-sample & 9,88 & 9,90 & 9,86 & 9,86 & 9,86 \\
\hline \multirow{2}{*}{ IHPB,UB,SB } & in-sample & 1,93 & 1,95 & 1,96 & 1,98 & 1,94 \\
\hline & out-sample & 2,68 & 4,22 & 5,05 & 5,44 & 4,30 \\
\hline \multirow{2}{*}{$\mathrm{CD}, \mathrm{UB}, \mathrm{SB}$} & in-sample & 49,46 & 48,98 & 45,95 & 43,82 & 40,94 \\
\hline & out-sample & 49,58 & 45,87 & 40,56 & 34,47 & 39,76 \\
\hline \multirow{2}{*}{ IHPB,CD,UB,SB } & in-sample & 50,56 & 58,10 & 55,80 & 55,20 & 49,65 \\
\hline & out-sample & 38,19 & 86,72 & 12,18 & 97,30 & 13,75 \\
\hline
\end{tabular}

Berdasarkan studi empiris terhadap konsistensi pemilihan input optimal dengan perulangan lima kali yang tersaji pada Tabel 9, menunjukkan bahwa nilai MAPE in-sample dengan input Indeks Harga Perdagangan Besar (IHPB), Uang Beredar (UB) dan Suku Bunga (SB) selalu terpilih menjadi MAPE in-sample yang terkecil. Sedangkan nilai MAPE pada out-sample dengan input IHPB, UB dan SB dari kelima perulangan tersebut berada pada rentang $0 \%<\mathrm{MAPE} \leq 10 \%$, hal itu menunjukkan bahwa performa kinerja model RANFIS dengan input IHPB, UB dan SB memiliki tingkat akurasi pemodelan yang sangat baik. Dengan demikian diperoleh kesimpulan bahwa input optimal pada teknik FCM dengan tipe fungsi keanggotaan gauss, dan cluster sebanyak 2 adalah variabel IHPB, UB dan SB. 


\subsection{Pemilihan Banyaknya Cluster yang Optimal}

Setelah mendapatkan input optimal pada model RANFIS yaitu variabel Indeks Harga Perdagangan Besar (IHPB), Uang Beredar (UB) dan Suku Bunga (SB), selanjutnya akan ditentukan banyaknya cluster dan jumlah aturan pada model RANFIS dengan teknik FCM. Perbandingan pemodelan RANFIS dengan cluster sebanyak 2 dan 3 tersaji pada tabel 2 .

Tabel 2. Perbandingan Nilai MAPE Model RANFIS antara Cluster sebanyak 2 dan 3

\begin{tabular}{lccccccc}
\hline \multirow{2}{*}{ Cluster } & \multirow{2}{*}{ Aturan } & & \multicolumn{5}{c}{ Nilai MAPE untuk Ulangan ke } \\
\cline { 3 - 7 } & & Data & 1 & 2 & 3 & 4 & 5 \\
\hline \multirow{2}{*}{$\left.\begin{array}{lllll}2 & 2 & 2\end{array}\right]$} & \multirow{2}{*}{2} & in-sample & $1,93 \%$ & $1,95 \%$ & $1,94 \%$ & $1,98 \%$ & $1,96 \%$ \\
& & out-sample & $2,68 \%$ & $4,22 \%$ & $4,30 \%$ & $5,44 \%$ & $5,05 \%$ \\
\hline \multirow{2}{*}{$\left.\begin{array}{lllll}3 & 3 & 3\end{array}\right]$} & \multirow{2}{*}{3} & in-sample & $3,44 \%$ & $3,34 \%$ & $3,79 \%$ & $3,57 \%$ & $3,58 \%$ \\
& & out-sample & $4,30 \%$ & $4,83 \%$ & $4,68 \%$ & $4,69 \%$ & $5,23 \%$ \\
\hline
\end{tabular}

Berdasarkan studi empiris terhadap konsistensi pemilihan banyaknya cluster optimal dengan perulangan lima kali yang tersaji pada Tabel 10, menunjukkan bahwa nilai MAPE in-sample dengan cluster sebanyak 2 selalu terpilih menjadi MAPE in-sample yang terkecil. Sedangkan nilai MAPE pada out-sample dengan cluster sebanyak 2 dari kelima perulangan tersebut berada pada rentang $0 \%<\mathrm{MAPE} \leq 0 \%$, hal itu menunjukkan bahwa performa kinerja model RANFIS dengan cluster sebanyak 2 memiliki tingkat akurasi pemodelan yang sangat baik. Dengan demikian dapat disimpulkan bahwa model RANFIS optimal pada Penelitian ini yakni menggunakan teknik FCM dengan input variabel IHPB, UB dan SB; tipe fungsi keanggotaan gauss; serta cluster sebanyak 2 yang diukur berdasarkan nilai MAPE in-sample sebesar 1,93\% dan MAPE out-sample sebesar 2,68\%.

Pada model RANFIS optimal, dapat dilihat plot perbandingan data target dan data output seperti pada Gambar 2.
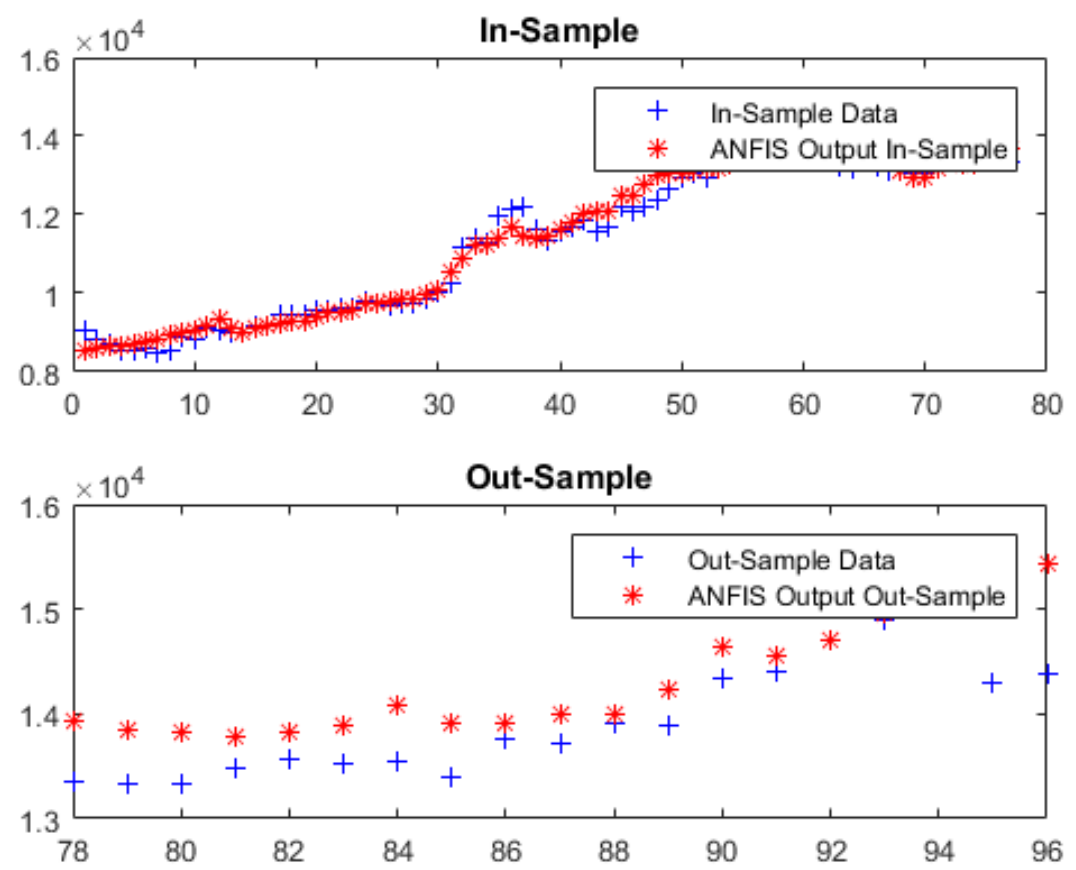

Gambar 2. Perbandingan Target dan Output RANFIS Optimal 
Berdasarkan Gambar 5, terlihat bahwa data output RANFIS pada in-sample mengikuti pergerakan data target. Begitupula data output RANFIS pada out-sample juga mengikuti data target.

\subsection{Pemodelan RANFIS}

Pemodelan RANFIS optimal menggunakan teknik FCM dengan cluster sebanyak [2 2 2], maka terbentuk 2 aturan sebagai berikut:

1. IF $\left(x_{1}\right.$ is $\left.A_{1}\right)$ and $\left(x_{2}\right.$ is $\left.B_{1}\right)$ and $\left(x_{3}\right.$ is $\left.C_{1}\right)$ THEN $y_{1}=p_{11} x_{1}+q_{12} x_{2}+r_{13} x_{3}+$ $s_{1}$

2. IF $\left(x_{1}\right.$ is $\left.A_{2}\right)$ and $\left(x_{2}\right.$ is $\left.B_{2}\right)$ and $\left(x_{3}\right.$ is $\left.C_{2}\right)$ THEN $y_{2}=p_{21} x_{1}+q_{22} x_{2}+r_{23} x_{3}+$ $S_{2}$

dengan, $x_{1}$ adalah variabel Indeks Harga Perdagangan Besar (IHPB), $x_{2}$ adalah variabel Uang Beredar (UB) dan $x_{3}$ adalah variabel Suku Bunga (SB). Adapun parameter premisnya yaitu $A_{1}, B_{1}, C_{1}, A_{2}, B_{2}$, dan $C_{2}$. Dengan $A_{1}$ adalah data pada $x_{1}$ yang masuk pada cluster 1 , $B_{1}$ adalah data pada $x_{2}$ yang masuk pada cluster $1, C_{1}$ adalah data pada $x_{3}$ yang masuk pada cluster $1, A_{2}$ adalah data pada $x_{1}$ yang masuk pada cluster $2, B_{2}$ adalah data pada $x_{2}$ yang masuk pada cluster $2, C_{2}$ adalah data pada $x_{3}$ yang masuk pada cluster 2 . Sedangkan parameter konsekuennya yaitu $p_{11}, q_{12}, r_{13}, s_{1}, p_{21}, q_{22}, r_{23}$, dan $s_{2}$.

\section{a. Lapis an 1}

Pada lapisan 1 dalam arsitektur RANFIS terdapat 6 kelompok nilai awal parameter nonlinear atau premis, dengan nilai-nilai tersebut akan digunakan untuk proses pembelajaran. Dengan menggunakan konsep gradient descent pada pembelajaran model RANFIS Optimal diperoleh nilai parameter premis atau nonlinear yang diperbaiki secara mundur dari lapisan 5 hingga lapisan 1 . Nilai parameter premis atau nonlinear yang telah diperbaiki dapat dilihat pada Tabel 3.

Tabel 3. Nilai Parameter Nonlinear Hasil Pembelajaran dari Model RANFIS Optimal

\begin{tabular}{cc}
\hline Kelompok & Nilai Parameter Nonlinier \\
\hline \multirow{2}{*}{$\mathrm{A}_{1}$} & $\sigma_{11}=28,58$ \\
& $\mathrm{c}_{11}=144,2$ \\
\hline \multirow{2}{*}{$\mathrm{B}_{1}$} & $\sigma_{21}=799700$ \\
& $\mathrm{c}_{21}=4489000$ \\
\hline \multirow{2}{*}{$\mathrm{C}_{1}$} & $\sigma_{31}=4,043$ \\
& $\mathrm{c}_{31}=6,61$ \\
\hline \multirow{2}{*}{$\mathrm{A}_{2}$} & $\sigma_{12}=38,44$ \\
& $\mathrm{c}_{12}=185,7$ \\
\hline \multirow{2}{*}{$\mathrm{B}_{2}$} & $\sigma_{22}=793100$ \\
& $\mathrm{c}_{22}=3041000$ \\
\hline \multirow{2}{*}{$\mathrm{C}_{2}$} & $\sigma_{32}=2,12$ \\
& $\mathrm{c}_{32}=6,318$ \\
\hline
\end{tabular}

Berdasarkan Tabel 12, menunjukkan bahwa hasil estimasi parameter premis awal memiliki selisih yang tidak terlalu besar dengan hasil estimasi parameter premis hasil pembelajaran. Pada penelitian ini fungsi keanggotaan yang digunakan yaitu gauss dengan rumus $\mu\left(x_{i}\right)=$ 
ISSN: 2339-2541

JURNAL GAUSSIAN, Volume 9, Nomor 2, Tahun 2020, Halaman 193-203

Online di: https://ejournal3.undip.ac.id/index.php/gaussian/

$e^{-\frac{1}{2}\left(\frac{x-c}{\sigma}\right)^{2}}$.Sehingga fungsi keanggotaan gauss yang terbentuk untuk mendapatkan derajat keanggotaan dengan nilai parameter premis pada Tabel 12 secara matematis dapat ditulis sebagai berikut:
1. $\mu_{A_{1}}\left(x_{1} ; \sigma_{11} ; c_{11}\right)=\exp \left[-\frac{1}{2}\left(\frac{x_{1}-144,2}{28,58}\right)^{2}\right]$
2. $\mu_{B_{1}}\left(x_{2} ; \sigma_{21} ; c_{21}\right)=\exp \left[-\frac{1}{2}\left(\frac{x_{2}-4489000}{799700}\right)^{2}\right]$
3. $\mu_{C_{1}}\left(x_{3} ; \sigma_{31} ; c_{31}\right)=\exp \left[-\frac{1}{2}\left(\frac{x_{3}-6,61}{4,043}\right)^{2}\right]$
4. $\mu_{A_{2}}\left(x_{1} ; \sigma_{12} ; c_{12}\right)=\exp \left[-\frac{1}{2}\left(\frac{x_{1}-185,7}{38,44}\right)^{2}\right]$
5. $\mu_{B_{2}}\left(x_{2} ; \sigma_{22} ; c_{22}\right)=\exp \left[-\frac{1}{2}\left(\frac{x_{2}-3041000}{793100}\right)^{2}\right]$
6. $\mu_{C_{2}}\left(x_{3} ; \sigma_{32} ; c_{32}\right)=\exp \left[-\frac{1}{2}\left(\frac{x_{3}-6,318}{2,12}\right)^{2}\right]$

\section{b. Lapis an 2}

Output lapisan 1 yang berupa derajat keanggotaan digunakan sebagai input pada lapisan 2 sehingga menghasilkan derajat pengaktifan tiap aturan. Pada model RANFIS optimal tersebut memiliki 2 aturan, maka output lapisan 2 berupa $w_{1}$ dan $w_{2}$ yang secara matematis dapat dituliskan sebagai berikut:.

$$
\begin{aligned}
& w_{1}=\mu_{A_{1}}\left(x_{1}\right) \cdot \mu_{B_{1}}\left(x_{2}\right) \cdot \mu_{C_{1}}\left(x_{3}\right) \\
& w_{1}=\exp \left(\left[-\frac{1}{2}\left(\frac{x_{1}-144,2}{28,58}\right)^{2}\right]+\left[-\frac{1}{2}\left(\frac{x_{2}-4489000}{799700}\right)^{2}\right]+\left[-\frac{1}{2}\left(\frac{x_{3}-6,61}{4,043}\right)^{2}\right]\right) \\
& w_{2}=\mu_{A_{2}}\left(x_{1}\right) \cdot \mu_{B_{2}}\left(x_{2}\right) \cdot \mu_{C_{2}}\left(x_{3}\right) \\
& w_{2}=\exp \left(\left[-\frac{1}{2}\left(\frac{x_{1}-185,7}{38,44}\right)^{2}\right]+\left[-\frac{1}{2}\left(\frac{x_{2}-3041000}{793100}\right)^{2}\right]+\left[-\frac{1}{2}\left(\frac{x_{3}-6,318}{2,12}\right)^{2}\right]\right)
\end{aligned}
$$

\section{c. Lapisan 3}

Output pada lapisan $2\left(\mathrm{w}_{1}\right.$ dan $\left.\mathrm{w}_{2}\right)$ digunakan sebagai input pada lapisan 3 yang akan dilakukan normalisasi pada derajat pengaktifan tersebut, maka output lapisan 3 berupa $\bar{w}_{1}$ dan $\bar{w}_{2}$. Secara matematis dapat dituliskan sebagai berikut:.

$$
\begin{aligned}
& \bar{w}_{i}=\frac{w_{i}}{\sum_{i=1}^{2} w_{i}} ; \mathrm{i}=1,2 \\
& \bar{w}_{1}=\frac{w_{1}}{w_{1}+w_{2}} \\
& \bar{w}_{2}=\frac{w_{2}}{w_{1}+w_{2}}
\end{aligned}
$$

\section{d. Lapisan 4}

Pada lapisan 4 diperoleh parameter linear atau konsekuen dari hasil pembelajaran Least Squares Estimastor (LSE) Rekursif. Parameter-parameter konsekuen tersebut dapat dilihat pada bentuk linear untuk setiap aturan sebagai berikut :

1. $y_{1}=-14,97 x_{1}+0,002048 x_{2}+404,4 x_{3}+3701$

2. $y_{2}=23,07 x_{1}+0,001358 x_{2}+526,2 x_{3}-2285$

\section{e. Lapis an 5}

Berdasarkan parameter konsekuen yang terbentuk, output lapisan 4 berupa $\bar{w}_{1} y_{1}$ dan $\bar{w}_{2} y_{2}$. Pada lapisan 5, output dari lapisan 4 akan dijumlahkan dan diperoleh model sebagai berikut :

$$
\begin{aligned}
& \hat{y}=\sum_{i=1}^{2} \bar{w}_{i}\left(p_{i 1} x_{1}+q_{i 2} x_{2}+r_{i 3} x_{3}+s_{i}\right) \\
& \hat{y}=\bar{w}_{1}\left(p_{11} x_{1}+q_{12} x_{2}+r_{13} x_{3}+s_{1}\right)+\bar{w}_{2}\left(p_{21} x_{1}+q_{22} x_{2}+r_{23} x_{3}+s_{2}\right)
\end{aligned}
$$




$$
\begin{aligned}
& \hat{y}=\bar{w}_{1}\left(-14,97 x_{1}+0,002048 x_{2}+404,4 x_{3}+3701\right)+\bar{w}_{2}\left(23,07 x_{1}+\right. \\
& \left.\quad 0,001358 x_{2}+526,2 x_{3}-2285\right) \\
& \text { dengan } \bar{w}_{1}=\frac{w_{1}}{w_{1}+w_{2}}, \bar{w}_{2}=\frac{w_{2}}{w_{1}+w_{2}} \\
& w_{1}=\exp \left(\left[-\frac{1}{2}\left(\frac{x_{1}-144,2}{28,58}\right)^{2}\right]+\left[-\frac{1}{2}\left(\frac{x_{2}-4489000}{799700}\right)^{2}\right]+\left[-\frac{1}{2}\left(\frac{x_{3}-6,61}{4,043}\right)^{2}\right]\right) \\
& w_{2}=\exp \left(\left[-\frac{1}{2}\left(\frac{x_{1}-185,7}{38,44}\right)^{2}\right]+\left[-\frac{1}{2}\left(\frac{x_{2}-3041000}{793100}\right)^{2}\right]+\left[-\frac{1}{2}\left(\frac{x_{3}-6,318}{2,12}\right)^{2}\right]\right)
\end{aligned}
$$

\subsection{Evaluasi Kinerja Model RANFIS}

Pada model RANFIS optimal diperoleh nilai MAPE in-sample sebesar 1,93\% dan nilai MAPE pada out-sample sebesar 2,68\%. Nilai MAPE pada out-sample berada pada rentang $0 \%<$ MAPE $\leq 10 \%$, hal ini menunjukkan bahwa evaluasi kinerja model RANFIS menggunakan teknik FCM dengan input IHPB, UB, dan SB; fungsi keanggotaan gauss; cluster sebanyak 2 dan jumlah aturan sebanyak 2 memiliki tingkat akurasi pemodelan yang sangat baik.

\section{KESIMPULAN}

Berdasarkan hasil analisis dan pembahasan yang telah dilakukan, maka diperoleh kesimpulan sebagai berikut :

1. Berdasarkan hasil kajian data empiris terhadap kurs IDR/USD, diperoleh model RANFIS optimal dengan input optimal/ faktor yang memiliki pengaruh terbesar terhadap kurs IDR/USD adalah variabel Indeks Harga Perdagangan Besar(IHPB), Uang Beredar (UB) dan Suku Bunga (SB), dengan tipe fungsi keanggotaan gauss, dan cluster sebanyak 2.

2. Diperoleh model RANFIS optimal:

$$
\begin{aligned}
& \hat{y}=\bar{w}_{1}\left(-14,97 x_{1}+0,002048 x_{2}+404,4 x_{3}+3701\right)+\bar{w}_{2}\left(23,07 x_{1}+\right. \\
& \left.0,001358 x_{2}+526,2 x_{3}-2285\right) \\
& \text { dengan } \bar{w}_{1}=\frac{w_{1}}{w_{1}+w_{2}} \\
& \bar{w}_{2}=\frac{w_{2}}{w_{1}+w_{2}} \\
& w_{1}=\exp \left(\left[-\frac{1}{2}\left(\frac{x_{1}-144,2}{28,58}\right)^{2}\right]+\left[-\frac{1}{2}\left(\frac{x_{2}-4489000}{799700}\right)^{2}\right]+\left[-\frac{1}{2}\left(\frac{x_{3}-6,61}{4,043}\right)^{2}\right]\right) \\
& w_{2}=\exp \left(\left[-\frac{1}{2}\left(\frac{x_{1}-185,7}{38,44}\right)^{2}\right]+\left[-\frac{1}{2}\left(\frac{x_{2}-3041000}{793100}\right)^{2}\right]+\left[-\frac{1}{2}\left(\frac{x_{3}-6,318}{2,12}\right)^{2}\right]\right)
\end{aligned}
$$

3. Model RANFIS optimal menghasilkan MAPE in-sample sebesar 1,93\% dan MAPE outsample sebesar $2,68 \%$, sehingga performa kinerja model RANFIS memiliki tingkat akurasi yang sangat baik.

\section{DAFTAR PUSTAKA}

Ariefianto, M.D. 2012. Ekonometrika Esensi dan Aplikasi dengan Menggunakan Eviews. Jakarta: Erlangga.

Adiningsih, S. 1998. Perangkat Analisis dan Teknik Analisis Investasi Pasar Modal indonesia. Jakarta: P.T. Bursa Efek Jakarta

Bank Indonesia. Statistik Ekonomi dan Keuangan Indonesia. Berbagai edisi penerbitan dan website : www.bi.go.id . Jakarta : Bank Indonesia.

Jang, J.S.R., Sun, C.T., dan Mizutani, E. 1997. Neuro Fuzzy and Soft Computing: A Computational Approach to Learning andMachine Intelligence. London: PranticeHall, Inc. 
Kusumadewi, S., dan Hartati, S. 2006. Neuro Fuzzy: Integrasi Sistem Fuzzy \& Jaringan Syaraf. Yogyakarta: Graha Ilmu.

Sari, S.K., Tarno, dan Safitri, D. 2017. Pemilihan Input Model Regression Adaptive Neuro Fuzzy Inference System (RANFIS) untuk Kajian Data IHSG. Jurnal Gaussian Vol. 6, No. 3: Hal. 449-458

Suliyanto. 2011. Ekonometrika Terapan: Teori \& Aplikasi dengan SPSS. Yogyakarta: ANDI.

Tarno, Subanar, Rosadi, D., dan Suhartono. 2013. Analysis of Financial Time Series Data Using Adaptive Neuro Fuzzzy Inference System (ANFIS). IJCSI Vol.10, Issue 2, No.1: Hal 491-496.

Triyono. 2008. Analisis Perubahan Kurs RupiahTerhadap Dollar Amerika. Fakultas Ekonomi Universitas Muhammadiyah Surakarta. Jurnal Ekonomi Pembangunan Vol 9, No. 2 : Hal 156-167.

Wijiyanto, A.N., Kusrini, D.E., dan Wijiyanto, I. 2012. Peramalan Nilai Kontrak Konstruksi PT ' $X$ ' dengan Menggunakan Pendekatan Regresi Time Series dan ANFIS. Jurnal Sains dan Seni ITS Vol.1, No.1: Hal D201-D206. 